\title{
Estimation of physicochemical properties of 2-ethylhexyl-4-methoxycinnamate (EHMC) degradation products and their toxicological evaluation
}

\author{
Alicja Gackowska ${ }^{1}$ - Waldemar Studziński ${ }^{1}$ - Edyta Kudlek ${ }^{2}$. Mariusz Dudziak ${ }^{2}$ - Jerzy Gaca ${ }^{1}$
}

Received: 12 January 2018 / Accepted: 19 March 2018 / Published online: 28 March 2018

(C) The Author(s) 2018

\begin{abstract}
The organic UV filters, commonly used in personal protection products, are of concern because of their potential risk to aquatic ecosystems and living organisms. One of UV filters is ethylhexyl-4-methoxycinnamate (EHMC) acid. Studies have shown that, in the presence of oxidizing and chlorinating factors, EHMC forms a series of products with different properties than the substrate. In this study, the toxicities of EHMC and its transformation/degradation products formed under the influence of $\mathrm{NaOCl} / \mathrm{UV}$ and $\mathrm{H}_{2} \mathrm{O}_{2} / \mathrm{UV}$ systems in the water medium were tested using Microtox® bioassay and by observation of mortality of juvenile crustaceans Daphnia magna and Artemia Salina. We have observed that oxidation and chlorination products of EHMC show significantly higher toxicity than EHMC alone. The toxicity of chemicals is related to their physicochemical characteristic such as lipophilicity and substituent groups. With the increase in lipophilicity of products, expressed as log $K_{\mathrm{OW}}$, the toxicity $\left(\mathrm{EC}_{50}\right)$ increases. On the basis of physicochemical properties such as vapour pressure (VP), solubility $(S)$, octanol-water partition coefficient $\left(K_{\mathrm{OW}}\right)$, bioconcentration factor $(\mathrm{BCF})$ and half-lives, the overall persistence $\left(P_{\mathrm{OV}}\right)$ and longrange transport potential (LRTP) of all the products and EHMC were calculated. It was shown that the most persistent and traveling on the long distances in environment are methoxyphenol chloroderivatives, then methoxybenzene chloroderivatives, EHMC chloroderivatives, methoxybenzaldehyde chloroderivatives and methoxycinnamate acid chloroderivatives. These compounds are also characterised by high toxicity.
\end{abstract}

Keywords EHMC transformation products $\cdot$ Physicochemical properties $\cdot$ EPI suite $\cdot P_{\mathrm{OV}} \cdot$ LRTP $\cdot$ Toxicity

Highlights

- Toxicity of EHMC transformation products was studied

- Analysis of EHMC transformation products in terms of their persistence

in environment and ability to propagate in air and water

- Application of the EPI Suite program to determine values of the selected physicochemical parameters of EHMC and its conversion products

Responsible editor: Ester Heath

Electronic supplementary material The online version of this article (https://doi.org/10.1007/s11356-018-1796-6) contains supplementary material, which is available to authorized users.

Alicja Gackowska

alicja.gackowska@utp.edu.pl

1 Faculty of Chemical Technology and Engineering, UTP University of Science and Technology, Seminaryjna 3,

85-326 Bydgoszcz, Poland

2 Institute of Water and Wastewater Engineering, Silesian University of Technology, Konarskiego 18, 44-100 Gliwice, Poland

\section{Introduction}

Chemical UV filters are used in personal protection products to protect our skin from harmful UV radiation. They are one of the components of sunscreens, lotions, shampoos, body washes, hair sprays and protective lipsticks (Ji et al. 2013; MacManus-Spencer et al. 2011). They are also added to paints and varnishes because they can prevent polymer degradation or pigmentation (Christiansson et al. 2009; Ferrari et al. 2013). One of the commonly used UV filter is 2-ethylhexyl-4methoxycinnamate ester (EHMC) (Kikuchi et al. 2011). EHMC shows a high absorbing capacity in the UVB range. The maximum permissible concentration of EHMC in cosmetic products in the European Union cannot exceed 10\% (Gilbert et al. 2013). Slightly smaller concentration, i.e. $7.5 \%$, is valid in the USA (Janjua et al. 2008).

The dynamic development of cosmetic industry has resulted in a higher consumption of chemical UV filters. Unfortunately, 
it has been observed that the chemical UV filters contribute to pollution of environment. EHMC has been detected in surface waters (Straub 2002; Poiger et al. 2004; Tarazona et al. 2010), swimming pool waters (Cuderman and Heath 2007; Santos et al. 2012), drinking water (Loraine and Pettigrove 2006; Diaz-Cruz et al. 2012), wastewater (Damiani et al. 2006; Li et al. 2007; Rodil et al. 2012), sewage sludge (De la Cruz et al. 2012; Zuloaga et al. 2012; Barón et al. 2013) and even in human breast milk and human urine (León et al. 2010). In treated wastewater, EHMC was identified at a level of 120 849 ng/L (Ekpeghere et al. 2016). Continuous and uncontrolled emission of the chemical UV filters into environment, even at low concentrations, is unfavourable as they accumulate in living organisms. EHMC accumulates in aquatic biota of different trophic levels with concentrations of up to $340 \mathrm{ng} / \mathrm{g}$ lipids in cormorants (Fent et al. 2010). EHMC is known as endocrine disrupting compound that cause adverse effects on human and wildlife. On this basis, the Commission of the European Union (EU 2015/495) placed EHMC on the list of 17 substances subjected to monitoring (Directive 2008/105/EC of the European Parliament and of the Council). EHMC has estrogenic properties both in vitro and in vivo (Schlumpf et al. 2001).

Recent studies have shown that EHMC under sun and UV irradiation forms transformation products (TPs) (MacManusSpencer et al. 2011; Rodil et al. 2009; Santiago-Morales et al. 2013; Vione et al. 2015). Under the influence of UV radiation and hydrogen peroxide, EHMC is degraded to compounds which, in the presence of reactive forms of oxygen or chlorine, can produce new products, sometimes even more toxic than the substrates themselves (Sakkas et al. 2003; Gackowska et al. 2014; Gackowska et al. 2016). In turn, in the presence of sodium hypochlorite used to disinfect pool waters, chloroorganic derivatives of EHMC are formed (Nakajima et al. 2009; Santos et al. 2012; Gackowska et al. 2016). Understanding the mechanism of EHMC transformations in the environment and the environmental fate of products of these transformations requires knowledge of their physicochemical properties such as water solubility $(S)$, octanolwater partition coefficient $\left(K_{\mathrm{OW}}\right)$, vapour pressure (VP) and bioconcentration factors as well as half-life in air, water and soil. Determination of the properties of all products is timeconsuming and sometimes difficult to perform. A useful tool for the determination of physicochemical parameters is EPI Suite. It allows estimating the physicochemical properties of all EHMC transformation products identified so far. Based on the calculated parameters and half-lives, the overall persistence $\left(P_{\mathrm{OV}}\right)$ and long-range transport potential (LRTP) of all EHMC transformation products were calculated with the Organization for Economic Cooperation and Development (OECD) $P_{\mathrm{OV}}$ and LRTP Screening Tool (http://www.oecd. org/document/24/0,3746,en_2649_34379_45373336_1_1_ 1_1,00.htm; Wegmann et al. 2009). The data obtained provide information on potential persistence of the transformation products and possible risks associated with their long-range transport in the environment.

From the toxicological point of view, the toxicity of EHMC degradation products is mostly unknown. There is no data on the environmental risk assessment of EHMC transformation products. In some cases, the toxicity of photolytic mixtures was tested e.g. Vibrio fischeri microtox assay for 4methoxybenzaldehyde that showed higher toxicity than EHMC (Vione et al. 2015). It should be noted that EHMC transformation products are formed at low concentrations in complex matrices. Their separation and isolation is laborious and difficult to perform. Hence, the toxicity assessment of a single product is difficult. The solution is to carry out a biotest for a mixture of compounds. Commonly applied test is Microtox ${ }^{\circledR}$ biotest, which uses natural luminescence of Vibrio fisheri exhibiting sensitivity to a wide spectrum of toxic organic and inorganic substances. (Hsieh et al. 2004; Bohdziewicz et al. 2016; Kudlek et al. 2016).

Other tests were carried out using the freshwater crustacean Daphnia magna (Rozas et al. 2016) and the saltwater crustacean Artemia salina (Vasquez and Fatta-Kassinos 2013).

The aims of the studies were to estimate physicochemical parameters and to model $P_{\mathrm{OV}}$ and LRTP for EHMC and its transformation products formed in oxidation, chlorination and photodegradation processes, simultaneously, to perform various ecotoxicological bioassays so as to be able to correlate if possible the findings between the physicochemical and biological assessments.

\section{Experimental}

\section{Materials and methods}

\section{Materials}

Analytical standard of 2-ethylhexyl 4-methoxycinnamate (EEHMC) (98\%) was obtained from ACROS Organics (USA) and was kept in lightproof container at $4{ }^{\circ} \mathrm{C}$. Sodium hypochlorite $\mathrm{NaOCl}$ with a nominal free chlorine content of $100 \mathrm{~g} \mathrm{~L}^{-1}$ and $\mathrm{H}_{2} \mathrm{O}_{2}(30 \%)$ was obtained from POCh (Poland). The toxicity tests: Microtox $\AA$, Daphtoxkit $F \AA$ and Artoxkit $M \circledR$ were purchased from MicroBioTest Inc. (Belgium).

\section{Oxidation processes}

The experimental oxidation processes were performed in a laboratory glass batch reactor with a capacity of $0.7 \mathrm{~L}$ of Heraeus (Hanau, Germany). The reactor was equipped with an immersion medium pressure UV lamp of $150 \mathrm{~W}$ located in a cooling jacket made of Duran 50 glass. The cooling process was performed with water from the mains. The cooling 
process enabled a constant temperature of $20 \pm 1{ }^{\circ} \mathrm{C}$ to be maintained. The lamp emitted radiation of $\lambda_{\text {exc }}$ equal to 313 , $365,405,436,546$ and $578 \mathrm{~nm}$. Additionally, the reactor was situated on a magnetic stirrer to guarantee the even mixing of contents during the execution process. The reaction conditions are presented in Table 1.

The research subjects were model solutions containing deionised water and E-EHMC model. In order to test toxicity of the E-EHMC oxidation and chlorination products, EEHMC solution at concentration of $3.4 \cdot 10^{-4} \mathrm{M}$ was prepared and subjected to the action of UV only, $\mathrm{H}_{2} \mathrm{O}_{2} / \mathrm{UV}$ and $\mathrm{NaOCl} /$ UV. The concentration of sodium hypochlorite and hydrogen peroxide were respectively $1.7 \cdot 10-5 \mathrm{M}$ and $0.05 \mathrm{M}$. After 30 , 60,90 and $180 \mathrm{~min}$, mixtures of the products obtained were sampled from reaction systems and subjected to toxicity tests. The effectiveness of E-EHMC elimination was assessed by monitoring for changes in concentrations of compound in water before and after the oxidation process, respectively.

\section{Method for the determination of EHMC transformation products}

A GC-MS 5890 HEWLETT PACKARD instrument equipped with column ZB-5MS $(0.25 \mathrm{~mm} \times 30 \mathrm{~m} \times 0.25 \mu \mathrm{m})$ was used for the identification of the transformation products applying the following chromatographic conditions: injector temperature $250{ }^{\circ} \mathrm{C}$, oven temperature program from 80 to $260{ }^{\circ} \mathrm{C}$ at $10{ }^{\circ} \mathrm{C} / \mathrm{min}$, from 260 to $300{ }^{\circ} \mathrm{C}$ (held for $2 \mathrm{~min}$ ) at a rate of $5^{\circ} \mathrm{C}$ min. Helium was used as a carrier gas. The volume of the sample was $1 \mu \mathrm{L}$. Reaction products were identified by comparing recorded MS spectra with standard spectra from NIST/EPA/NIH Mass Spectral Library. The detailed description of the methodology for identification of EHMC transformation products was presented in previous papers (Gackowska et al. 2014; Gackowska et al. 2016).

\section{Toxicity tests}

All samples from the reactor were diluted 1:100 before performing toxicity tests. Additionally, control tests were carried out. In order to eliminate the effects of the reagents, tests for E-EHMC-free systems were performed. Moreover, the toxicity tests were performed without EHMC. Changes in the toxicity of samples were assessed on the basis of the results from three biotests: Microtox $\AA$, Daphtoxkit $F \circledR$ and Artoxkit $M \circledR$. On the basis of the difference in results obtained for EHMC systems with and without EHMC, the toxicity of the mixture of transformation products was determined. All samples for toxicity tests were performer in four replicates.

Microtox ${ }^{\circledR}$ In Microtox ${ }^{\circledR}$ test, bioluminescent bacteria Aliivibrio fischeri, which are highly sensitive to a wide spectrum of toxic substances, were used. During exposure of
Table 1 The reaction conditions and substrate proportions used in this study

\begin{tabular}{lllll}
\hline Reagents & EHMC $[\mathrm{M}]$ & $\mathrm{H}_{2} \mathrm{O}_{2}[\mathrm{M}]$ & $\mathrm{NaOCl}[\mathrm{M}]$ & $\mathrm{UV}[\mathrm{W}]$ \\
\hline EHMC & $3.4 \cdot 10^{-4}$ & 0 & 0 & - \\
$\mathrm{EHMC} / \mathrm{UV}$ & $3.4 \cdot 10^{-4}$ & 0 & 0 & 150 \\
$\mathrm{EHMC} / \mathrm{NaOCl} / \mathrm{UV}$ & $3.4 \cdot 10^{-4}$ & 0 & $1.7 \cdot 10^{-5}$ & 150 \\
$\mathrm{EHMC} / \mathrm{H}_{2} \mathrm{O}_{2} / \mathrm{UV}$ & $3.4 \cdot 10^{-4}$ & 0.05 & 0 & 150 \\
$\mathrm{NaOCl} / \mathrm{UV}$ & 0 & 0 & $1.7 \cdot 10^{-5}$ & 150 \\
$\mathrm{H}_{2} \mathrm{O}_{2} / \mathrm{UV}$ & 0 & 0.05 & 0 & 150 \\
\hline
\end{tabular}

bacteria to toxic substances, the metabolic changes occur or population of bacteria is reduced, what in turn results in change in the intensity of light emitted by microorganisms. The test was conducted according to MicrotoxOmni Screening Test procedure in the Microtox Model 500 analyser from Tigret Sp. z o.o. (Poland), which operated both as an incubator and as a photometer. Percentage of bioluminescence inhibition relative to control sample (bacteria not exposed to toxicant) was measured after 5 and $15 \mathrm{~min}$ of exposure time (volume of samples $1 \mathrm{~mL}$ ). The $\mathrm{EC}_{50}$ value was determined on the basis of the Basic Dilution Test.

Daphtoxkit $\mathbf{F}^{\circledR}$ The test procedure is based on observation of the mortality of juvenile Daphnia magna crustaceans subjected to the action of toxicant. The results were checked after 24 and $28 \mathrm{~h}$ of exposure of animals to the tested solutions. All organisms that did not demonstrate a motion reaction to swirl induced by stirring the solution were considered dead. Experiment was carried out in accordance with the OECD Guideline 202 and ISO 6341 standards.

Artoxkit $\mathbf{M}^{\circledR}$ Toxicity of solutions was also tested on Artemia Salina crustaceans. Survival of indicatory organisms was assessed after $24 \mathrm{~h}$ of exposure to water solutions. The individuals showing no signs of life were recognised as dead. Test was conducted according to the ASTM E1440-91 standard.

The effect of the toxicity (\%) was determined according to the equation:

$E=\frac{100 \cdot\left(E_{\mathrm{K}}-E_{\mathrm{T}}\right)}{E_{\mathrm{K}}},[\%]$

where

$E_{\mathrm{K}} \quad$ the effect observed in a blank sample and

$E_{\mathrm{T}} \quad$ the effect observed in a test sample.

Depending on the given test, the effect was measured by the decrease in bioluminescence (i.e. the enzymatic Microtox ${ }^{\circledR}$ test) or organism viability (i.e. the Daphnia magna test and Artemia Salina test). 


\section{The evaluation of results}

The results are the arithmetic average of the four replicates of each experiment. For all the cases, assigned error (estimated based on the standard deviation) did not exceed $5 \%$, so the results are presented in the form of error bars.

\section{Results and discussion}

Based on the analysis of previous studies, the identified products of EHMC transformation have been gathered. These products have been presented in Supplementary (S Figs. 18 ) and the list of products studied was presented in Table 2.

In order to make a preliminary assessment of EHMC transformation products for potential threats to the environment, their characteristic physicochemical parameters were determined using EPI Suite program. The EPI (Estimation Programs Interface) Suite ${ }^{\mathrm{TM}}$ is a suite of physical/chemical properties, aquatic toxicity and environmental fate estimation programs jointly developed by the US EPA and Syracuse Research Corp. (SRC). The US EPA develops and uses models based on (quantitative) structure-activity relationships ([Q]SARs) to estimate critical parameters. Structure-activity relationship (SAR) and quantitative structure-activity relationship (QSAR) models are theoretical models that can be used to quantitatively or qualitatively predict the physicochemical, biological (e.g. an (eco) toxicological endpoint) and environmental fate properties of a chemical substance from the knowledge of its chemical structure.

The results were presented in Table 3. Analysis of parameters has shown that EHMC transformation products are characterised by different properties than the substrate.

\section{Boiling point and vapour pressure}

Boiling point (BP) and vapour pressure (VP) are the parameters that provide information on whether the compounds, after entering the environment, will evaporate into the atmosphere relatively quickly. Studies have shown that EHMC transformation

Table 2 List of chemicals

\begin{tabular}{|c|c|c|}
\hline No. & Abbreviation & Chemical name \\
\hline 1 & E-EHMC & trans 2-Ethylhexyl-4-methoxycinnamate \\
\hline 2 & EHA & 2-Ethylhexyl alcohol \\
\hline 3 & $4 \mathrm{MCA}$ & 4-Methoxycinnamic acid \\
\hline 4 & 4MBA & 4-Methoxybenzaldehyde \\
\hline 5 & 4MP & 4-Methoxyphenol \\
\hline 6 & $1 \mathrm{Cl} 4 \mathrm{MB}$ & 1-Chloro-4-methoxybenzene \\
\hline 7 & 1.3DCl2MB & 1.3-Dichloro-2-methoxybenzene \\
\hline 8 & 2-EHCA & 2-Ethylhexyl chloroacetate \\
\hline 9 & 3Cl4MBA & 3-Chloro-4-methoxybenzaldehyde \\
\hline 10 & Z-EHMC & cis 2-Ethylhexyl-4-methoxycinnamate \\
\hline 11 & $\mathrm{EHMCCl}$ & Chloro-2-Ethylhexyl-4-methoxycinnamate \\
\hline 12 & $\mathrm{EHMCCl}_{2}$ & Dichloro-2-Ethylhexyl-4-methoxycinnamate \\
\hline 13 & 2.4DCIP & 2.4-Dichlorophenol \\
\hline 14 & 2.6DCl1.4BQ & 2.6-Dichloro-1.4-benzoquinone \\
\hline 15 & $1.2 .4 \mathrm{TCl} 3 \mathrm{MB}$ & 1.2.4-Trichloro-3-methoxybenzene \\
\hline 16 & 2.4.6TCIP & 2.4.6-Trichlorophenol \\
\hline 17 & 3.5DCl2HAcP & 3.5-Dichloro-2-hydroxyacetophenone \\
\hline 18 & 3Cl4MCA & 3-Chloro-4-methoxycinnamic acid \\
\hline 19 & 3.5DC14MCA & 3.5-Dichloro-4-methoxycinnamic acid \\
\hline 20 & 3.5DCl4MBA & 3.5-Dichloro-4-methoxybenzaldehyde \\
\hline 21 & 3Cl4MP & 3-Chloro-4-methoxyphenol \\
\hline 22 & 2.5DCl4MP & 2.5-Dichloro-4-methoxyphenol \\
\hline 23 & $\mathrm{TP}_{199}$ & Transformation product \\
\hline 24 & $\mathrm{TP}_{307 \mathrm{e}}$ & Transformation product \\
\hline 25 & $\mathrm{TP}_{307 \mathrm{f}}$ & Transformation product \\
\hline 26 & $\mathrm{TP}_{305 \mathrm{a}}$ & Transformation product \\
\hline 27 & $\mathrm{TP}_{305 \mathrm{~b}}$ & Transformation product \\
\hline 28 & $\mathrm{TP}_{305 \mathrm{c}}$ & Transformation product \\
\hline 29 & $\mathrm{TP}_{305 \mathrm{~d}}$ & Transformation product \\
\hline 30 & $\mathrm{TP}_{305 \mathrm{e}}$ & Transformation product \\
\hline 31 & $\mathrm{TP}_{305 \mathrm{f}}$ & Transformation product \\
\hline 32 & $\mathrm{TP}_{469 \mathrm{a}}$ & Transformation product \\
\hline 33 & $\mathrm{TP}_{469 \mathrm{~b}}$ & Transformation product \\
\hline 34 & DIAMC & $\begin{array}{l}\text { 2.4-bis-((2Z.4E)-4-Methoxyhepta-2.4.6-trienyl)- } \\
\text { cyclobutane-1.3-dicarboxylic acid bis- } \\
\text { (3-methyl-butyl) ester }\end{array}$ \\
\hline 35 & $\mathrm{TP}_{581 \mathrm{~b}}$ & Transformation product \\
\hline
\end{tabular}




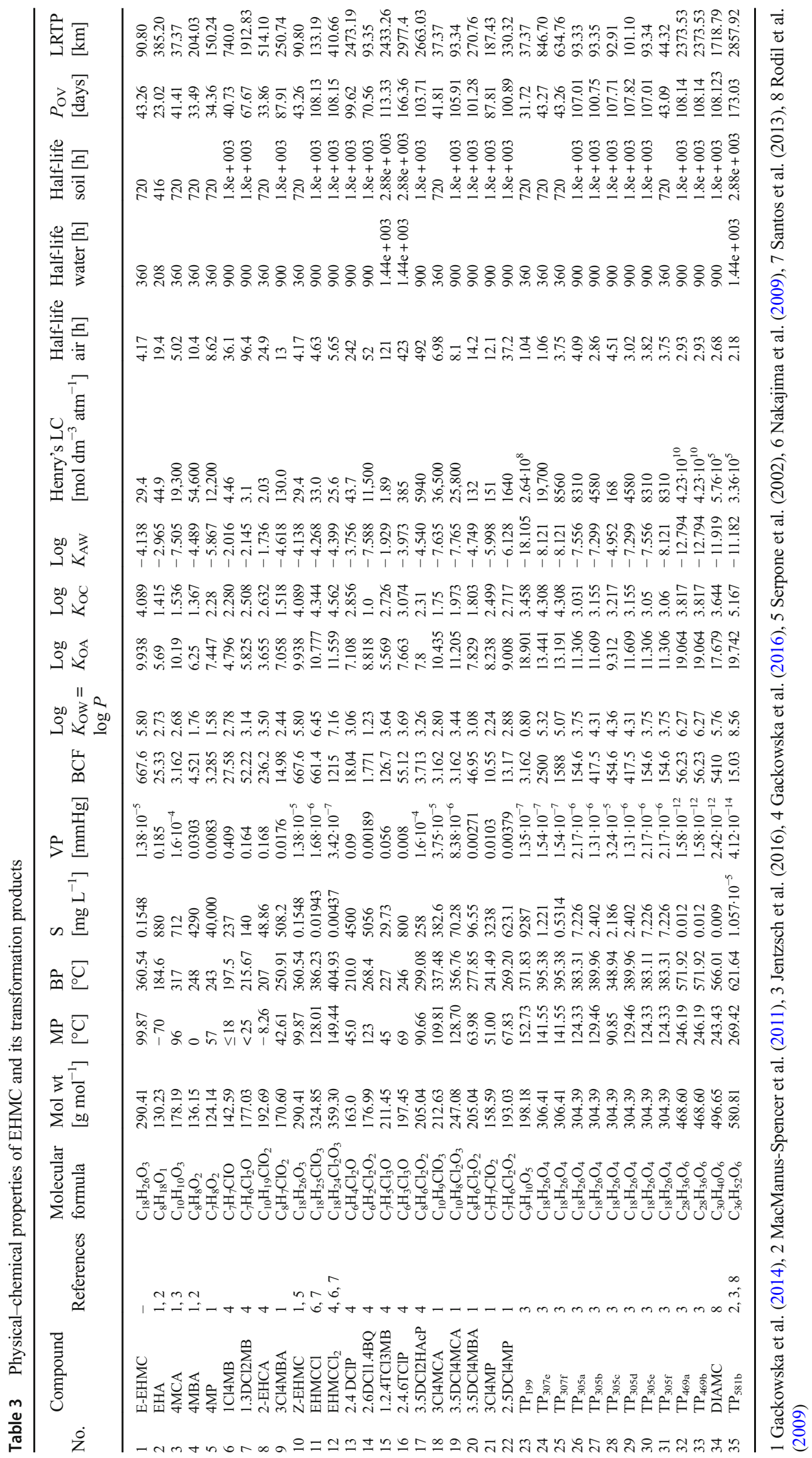


products can be classified as medium- or low-volatility compounds $\left(\mathrm{BP}>184^{\circ} \mathrm{C}\right)$. Medium-volatility compounds are: EHA; $1 \mathrm{Cl} 4 \mathrm{MB}$; $1,3 \mathrm{DC} 2 \mathrm{MB}$ and $2 \mathrm{EHCA}$ (BP $184-216^{\circ} \mathrm{C}$ ). The above-mentioned products are also characterised by the highest vapour pressure value, which ranges from 0.164 to $0.409 \mathrm{mmHg}$. Other products $\mathrm{TP}_{469 \mathrm{a}}, \mathrm{TP}_{469 \mathrm{~b}}$, DIAMC and $\mathrm{TP}_{581 \mathrm{~b}}$ belong to the group of low-volatility compounds. On the basis of the BP and VP, these transformation products have no predisposition to evaporate and be in gas phase (Table 3).

\section{Water solubility}

High solubility in water suggests that pollutants can migrate with water over long distances. Hydrophilic compounds also have the ability to be readily absorbed by plants. These pollutants can be phytotoxic by damaging shoots and roots, reducing plant growth and disturbing transpiration (Yu-Hong and Yong-Guan, 2006). In turn, pollutants with low solubility can accumulate in sediments.

Analysis of the results indicates that the products (besides Z-EHMC, EHMCCl, TP $469 \mathrm{a}, \mathrm{TP}_{469 \mathrm{~b}}$, DIAMC and $\mathrm{TP}_{581 \mathrm{~b}}$ ) are characterised by significantly better water solubility than the substrate (Fig. 1). Water solubility of EHMC at temperature of $25^{\circ} \mathrm{C}$ is lower than $0.1548 \mathrm{mg} \mathrm{L}^{-1}$. Considerably higher solubility $\left(1.0 \times 10^{3} \geq S \leq 1.0 \times 10^{2}\right)$ has the following oxidation products: $\mathrm{EHA}$ and $4 \mathrm{MCA}$, and chlorination products: $1 \mathrm{C} 14 \mathrm{MB}$; 1,3 DC12MB; 3C14MBA; 2,4,6 TCP ; 3,5DCl2HAcP; 3Cl4MCA and 2,5DCl4MP. Metabolites very well soluble in water $\left(S \leq 1.0 \times 10^{4} \mathrm{mg} \mathrm{L}^{-1}\right)$ are $4 \mathrm{MBA}$; $4 \mathrm{MP}$; 2,4DClP; $2,6 \mathrm{DC} 1,4 \mathrm{BQ} ; 3 \mathrm{Cl} 4 \mathrm{MP}$ and $\mathrm{TP}_{199}$. It should be noted that compounds with an $\mathrm{OH}$ and $\mathrm{Cl}$ group have high $S$ values. This pattern indicates that the partitioning potential from water to air of such chemicals is quite low. Among EHMC transformation products, 2,4-dichlorophenol (2,4DCIP), 2,4,6-trichlorophenol (2,4,6TClP) and benzene chloroderivatives deserve special attention. Due to their high toxicity to aquatic organisms (USEPA 1991; EC 2001; Xing et al. 2012;) and potentially carcinogenic properties, the international environmental organisations (WHO, UNEP, USEPA, EC) included chlorophenols into a group of pollutants with a special risk to the environment (WHO 1989; WHO 2003; UNEP 2001; USEPA 1991, USEPA 2014; EC 2001). These compounds were identified in surface water and groundwater (He et al. 2000; Czaplicka 2004; Gao et al. 2008; Sim et al. 2009). An example of drinking water pollution with chlorophenol (including 2,4,6TClP) in Finland shows how many effects can be caused by EHMC transformation products, where an increased incidence of gastrointestinal infections, asthma and depression morbidity was observed (Lampi 1992).

\section{Octanol/water partition coefficient}

Logarithmic value of octanol/water partition coefficient (log $K_{\mathrm{OW}}$ ) allows determining quantitatively lipophilic character of the compound. Octanol is considered as a representative of organic matter. Analysis of the results obtained showed that $\log K_{\mathrm{Ow}}$ EHMC was higher than 5 (Fig. 2). The value obtained is consistent with the data presented by Ramos et al. (2015). EHMC has lipophilic properties and can accumulate in sediments. Kupper et al. (2006) and Liu et al. (2012) showed that EHMC concentration in raw sludge is within the range from 13 to $14.45 \mathrm{ng} / \mathrm{g} \mathrm{dw}$; however, Langford et al. (2015) reported that it was up to $4689 \mathrm{ng} / \mathrm{g} \mathrm{dw}$ in treated sludge. The differences in concentration among authors is due to the variable composition of the sludge used, and more likely results from the variable organic matter content they had.

A similar lipophilic character has most of the analysed products for which the calculated coefficient $\log K_{\mathrm{OW}}>3$. EHMCCl, EHMCCl2, $\mathrm{TP}_{469 \mathrm{a}}, \mathrm{TP}_{469 \mathrm{~b}}$ and $\mathrm{TP}_{581 \mathrm{~b}}$ for which $\log K_{\mathrm{OW}}>6$ deserve a special attention. A different character have the products of EHMC oxidation: EHA; $4 \mathrm{MCA}$; 4MP; 3Cl4MBA; 2,6DCl1,4BQ; 1Cl4MB; 3Cl4MCA; 3Cl4MP;

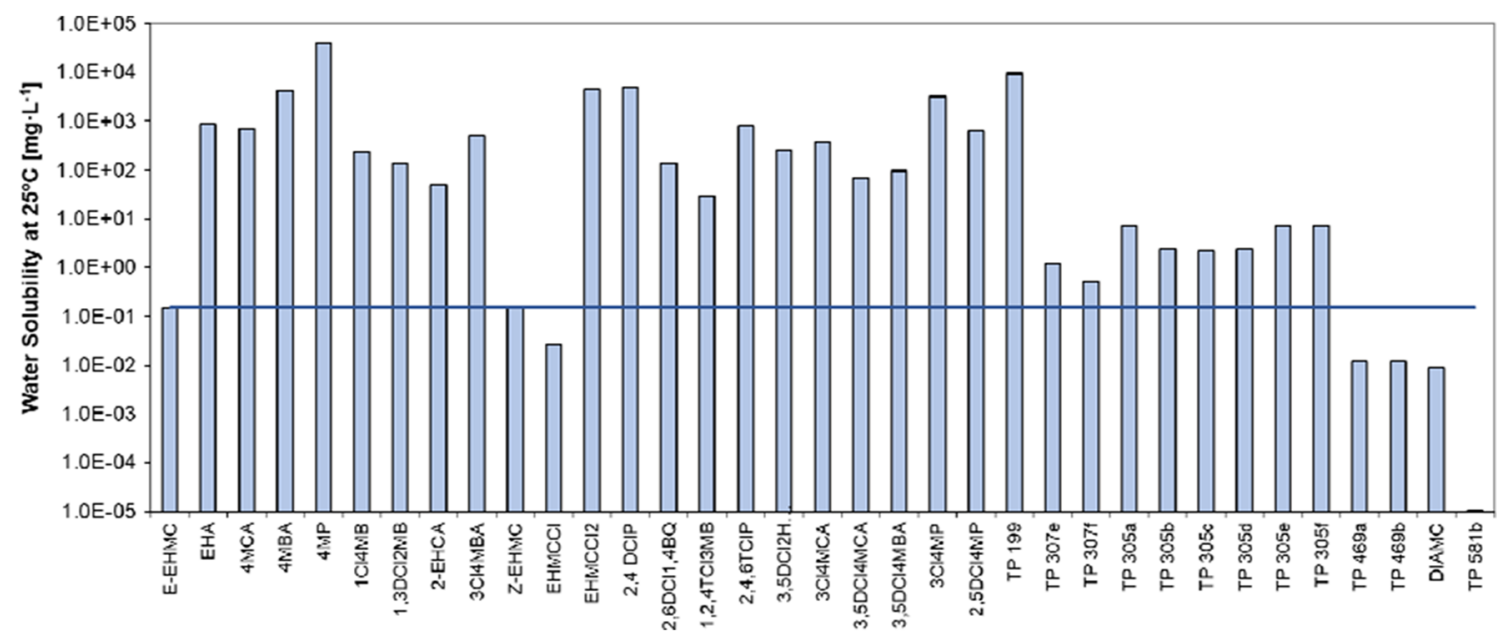

Fig. 1 Water solubility of EHMC transformation products 


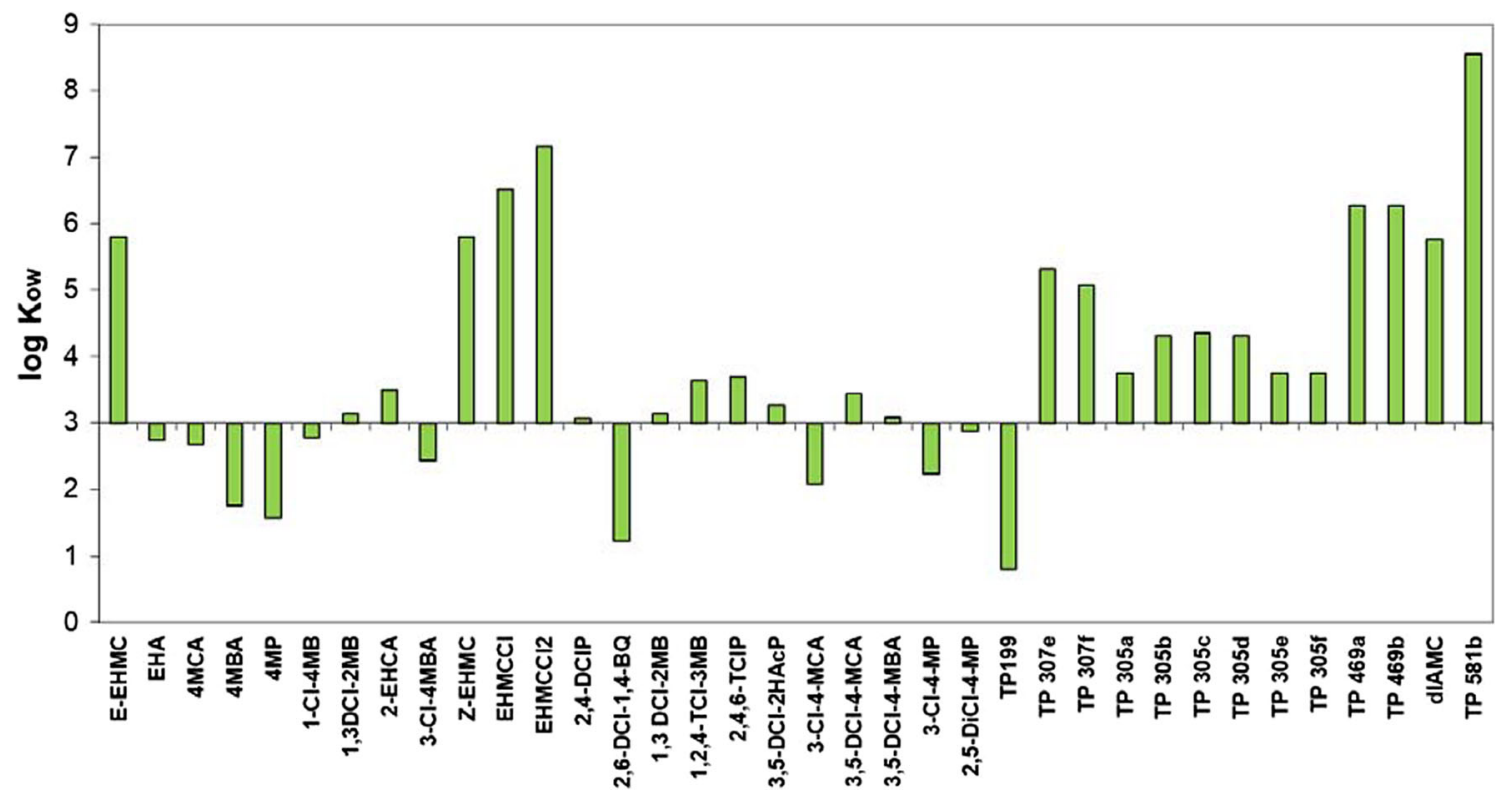

Fig. 2 Octanol/water coefficient ( $\log K_{\mathrm{OW}}$ ) of EHMC transformation products

2,5DCl4MP and $\mathrm{TP}_{199}$ (Fig. 2). Soluble compounds (log $K_{\mathrm{OW}}<3$ ) will not accumulate in organisms, soil or sediments but instead will be contaminating all water sources and thus spreading around larger areas. Cinnamic acid derivatives with high $\log K_{\mathrm{OW}}$ values show high phytotoxic potential (Jitareanu et al. 2011). According to Legierse et al. (1998), the rate of absorption of chloroderivatives by snails is directly proportional to $\log K_{\mathrm{OW}}$.

\section{Bioconcentration factor}

The ability of pollutants to bioconcentrate in living organisms is one of parameters taken into account in assessing a threat posed by the new environmental pollutants. For many compounds, there is a linear relationship between $\log K_{\mathrm{OW}}$ and bioconcentration factor (BCF), but this is not a rule, and each example should be considered separately (Axelman et al. 1995). Analysis of products showed that EHMC chloroderivatives (EHMCCl and $\mathrm{EHMCCl}_{2}$ ) were characterised by high bioconcentration factor $(\mathrm{BCF}>600)$ (Fig. 3). These are compounds with hydrophobic properties $\left(\log K_{\mathrm{OW}}>5\right)$. It is accepted that adipose tissue of living organisms is the place where the hydrophobic organic compounds are accumulated. Hydrophobicity is the principal determining factor of bioconcentration and plays a very important role in the bioconcentration of hydrophobic organic compounds (Wang et al. 2014). Hydrophilic compounds appear instead in soluble phases inside the organisms, such as blood serum and mother's milk (Armitage et al. 2013). They appear also in eggs (Lopez-Antia et al. 2017). They affect not only animals but also plants, where they appear in all plant tissues, including sap and nectar, and thus constitute a major problem in environmental contamination nowadays (Bonmatin et al.
2015). BCF of analysed products with hydrophylic character is in the range of $1.7<\mathrm{BCF}<56$. These include chloroderivatives of phenols, methoxybenzene or methoxycinnamic acid. For this group of compounds, no distinct relationship between $\log K_{\mathrm{OW}}$ and $\mathrm{BCF}$ was observed.

The bioconcentration ability of EHMC was confirmed by Fent et al. (2010). EHMC was identified in fish, cormorants and shellfish on a level of nanograms per gram and chlorophenols were present in urine, umbilical cord blood and mother's milk (Sandau et al. 2002; Bradman et al. 2003; Hong et al. 2005; Philippat et al. 2013; Kim et al. 2014; Forde et al. 2015). These compounds can cause unfavourable histopathological, genotoxic, mutagenic and carcinogenic effects in humans and animals (Igbinosa et al. 2013). Other metabolites that accumulate in the food chains and are ultimately identified in human adipose tissue, breast milk and blood are chlorobenzenes (Ivanciuc et al. 2005; Tor 2006; Kozani et al. 2007). Because EHMC transformations result in formation of many chloroorganic compounds at low concentrations, it should be checked how BCF of the mixture of products will change. According to Kondo et al. (2005), BCF of the mixture of chloroorganic compounds can be significantly higher than that of a single substance.

\section{Overall persistence and long-range transport potential}

As the environmental overall persistence $\left(P_{\mathrm{OV}}\right)$ and longrange transport potential (LRTP) of all transformation products cannot be determined in laboratory experiment, they have to be calculated utilising physical-chemical parameters such as n-octanol/water $\left(\log K_{\mathrm{OW}}\right)$, n-octanol/air $\left(\log K_{\mathrm{OA}}\right)$ and air/ water $\left(\log K_{\mathrm{AW}}\right)$ partition coefficients, as well as half-lives in 
Fig. 3 Bioconcentration factor (BCF) of EHMC transformation products with the highest $\mathrm{BCF}$ value

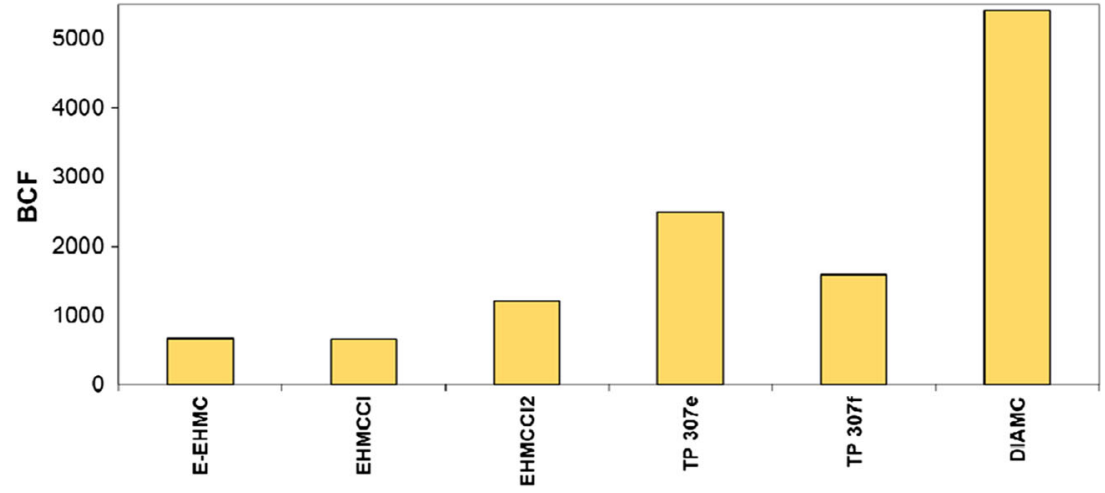

air, water, and soil and molar masses of compounds calculated by EPI Suite (Mackay and Webster 2006; Mostrag et al. 2010; Kuramochi et al. 2014). $P_{\mathrm{OV}}$ and LRTP of all the products and EHMC were calculated by $P_{\mathrm{OV}}$ and LRTP Screening Tool created by OECD. The tool requires estimated degradation half-lives in soil, water and air, and partition coefficients between air and water and between octanol and water as chemical specific input parameters. From these inputs, the tool calculates metrics of $P_{\mathrm{OV}}$ and LRTP from a multimedia chemical fate model and provides a graphical presentation of the results.

Studies on the environmental mobility of products showed that the highest long-range transport potential expressed by characteristic travel distance (CTD) was observed for methoxyphenol chloroderivatives, then methoxybenzene chloroderivatives, EHMC chloroderivatives, methoxybenzal dehyde chloroderivatives and methoxycinnamate acid chloroderivatives (S Fig. 9). It was observed that CTD increases with the increase of chlorine atoms in molecule. The impact of the compound structure, molar mass and type of atom in the individual molecules was described by Mostrag et al. (2010). In their opinion, there is a relationship between the long-range transport potential of pollutants and presence of halogens $(\mathrm{Cl}$, $\mathrm{F}, \mathrm{Br}$ ) in the molecule. However, each group of compounds should be analysed individually. Other products that can be transported over considerable distances in the environment are photodegradation products formed by the path of dimerization $\left(\mathrm{TP}_{469 \mathrm{a}}, \mathrm{TP}_{469 \mathrm{~b}}, \mathrm{TP}_{581 \mathrm{~b}}\right.$, dIAMC) (Vione et al. 2015). These compounds can travel up to $3000 \mathrm{~km}$ in the environment (Table 3). EHMC oxidation products (4MBA, 4MP, TP $305 \mathrm{a}-\mathrm{f}$ ) can be transported over much shorter distances. Similar relationships are observed in the case of the overall persistence. The most durable are chloroorganic products. $P_{\mathrm{OV}}$ of these compounds is in the range of 100-170 days. Similarly, EHMC oxidation products $\left(\mathrm{TP}_{305 \mathrm{a}-\mathrm{f}}\right)$ are also stable (S Fig. 10). On
Fig. $4 P_{\mathrm{OV}}$ and LRTP of the selected EHMC transformation products calculated by the OECD $P_{\mathrm{OV}}$ and LRTP Screening Tool using property date from EPI Suite

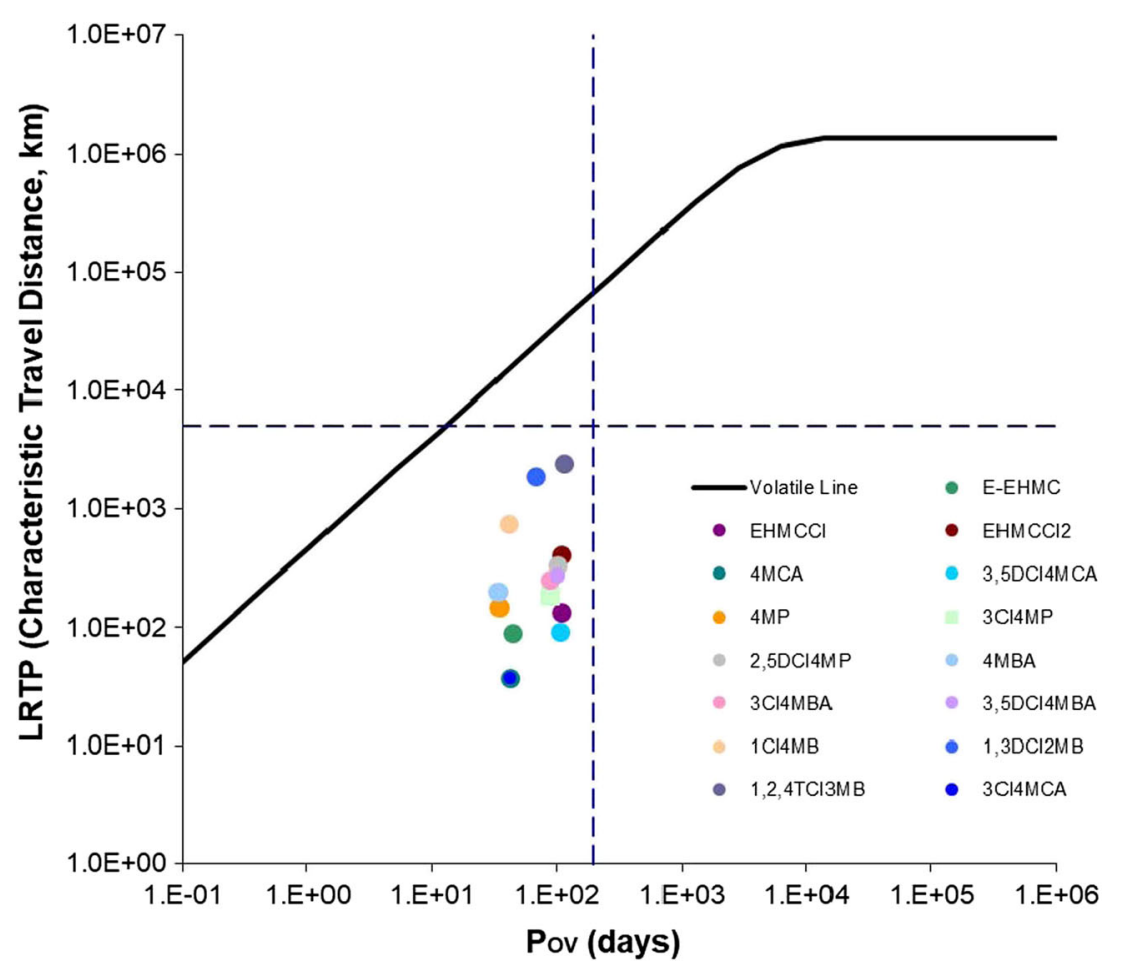


Fig. 5 Toxic effect of the systems studied, determined by Microtox ${ }^{\circledR}$ test after $90 \mathrm{~min}$ of reaction

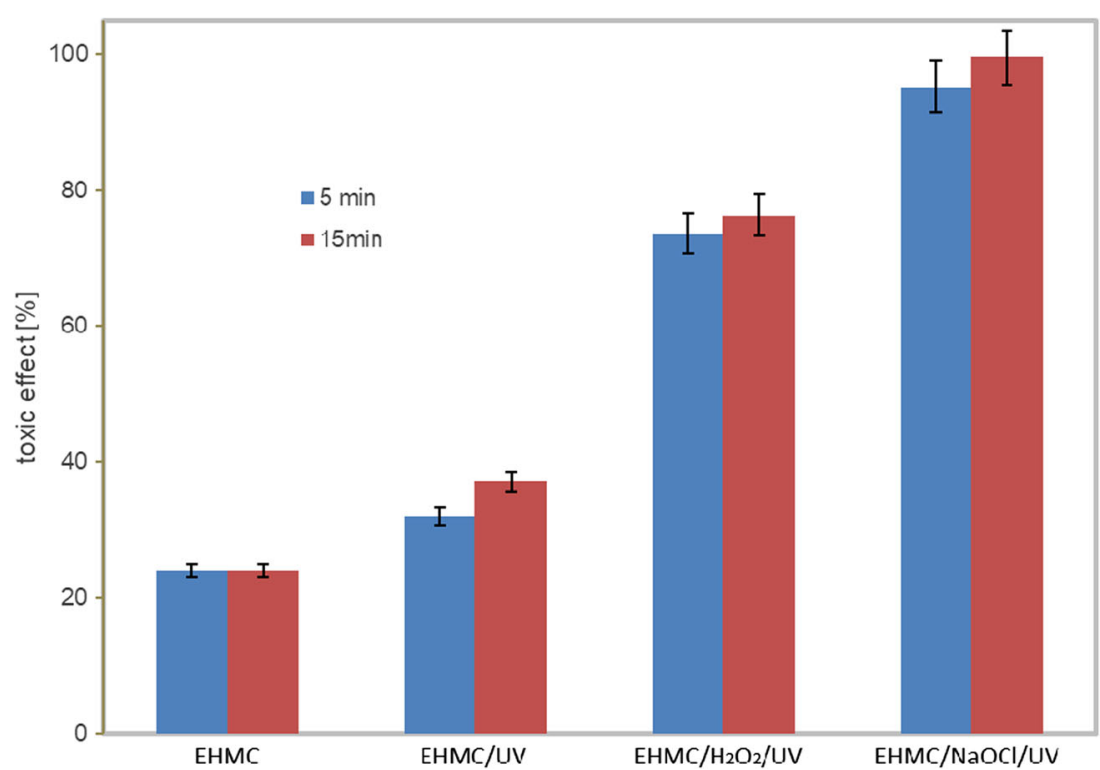

the basis of LRTP and $P_{\mathrm{OV}}$ values obtained, it can be determined to which class of persistent organic pollutants (POPs) the tested products are classified. Klasmeier et al. (2006) determined the critical values of LRTP and $P_{\mathrm{OV}}$ and divided pollutants into four classes: I class-persistent organic pollutants (POP-like) (pollutants of the "highest priority"), both parameters are higher than the critical value; II and III classes-molecules which have POP-like characteristic for one of the reference parameters, (pollutants of "intermediate priority") and IV class - pollutants with LRTP and $P_{\mathrm{OV}}$ lower than critical value (compounds of the "lowest priority"). LRTP and $P_{\mathrm{OV}}$ values of the products studied are lower than the critical value $\left(P_{\mathrm{OV}}\right.$ 195 days, LRTP_-5096.73 km); therefore, they can be classified into IV class (Fig. 4).

\section{Toxicity testing}

Toxicity of products was estimated by monitoring changes in the natural emission of the luminescent bacteria Aliivibrio fisheri and by observation of mortality of juvenile crustaceans Daphnia magna and Artemia Salina treated with solutions containing EHMC transformation products. The reaction mixtures EHMC/UV, EHMC/ $\mathrm{H}_{2} \mathrm{O}_{2} / \mathrm{UV}$ and $\mathrm{EHMC} / \mathrm{NaOCl} / \mathrm{UV}$ were tested after different times of reaction (S Figs. 11-17). In order to eliminate the effects of reagents, tests for reaction systems with/without EHMC were performed. Based on the difference in results obtained, the toxicity of the mixture of transformation products was determined.

Analysis of solutions from systems containing only oxidizing agents $\left(\mathrm{NaOCl} / \mathrm{UV}, \mathrm{H}_{2} \mathrm{O}_{2} / \mathrm{UV}\right)$ showed a slight toxic effect (S Figs. 11 and 12). After an hour of reaction, the toxic effect is close to zero. Figure 5 presents percentage of toxic effect of the systems studied (EHMC, EHMC/UV, EHMC/ $\mathrm{H}_{2} \mathrm{O}_{2} / \mathrm{UV}$, EHMC/NaOCl/UV), determined by Microtox ${ }^{\circledR}$ test after
$90 \mathrm{~min}$ of reaction. The toxicity classification of the mixture of products was performed based on the magnitude of effects observed in the indicator organisms. The toxicity classification system is presented in Table 4. Such a system is used by many researchers (Põllumaa et al. 2004; Ricco et al. 2004; Werle and Dudziak 2013). EHMC is characterised by low toxicity; toxic effect is lower than $30 \%$ (S Figs. 13 and 14). The acute toxicity shows the products formed as a result of EHMC reaction with $\mathrm{NaOCl}$ and UV. After 1.5-h-lasting reaction, toxic effect is higher than $90 \%$. In the system with hydrogen peroxide and UV, the toxic products are formed. The effect is on the level of $75 \%$. Low toxicity was observed in the system in which EHMC was exposed to UV. Toxic effect was about $30 \%$. Similar results were obtained using tests with Daphnia manga and Artemia Salina (S Figs. 15-17). Studies have shown that the presence of oxidizing and chlorinating agents affects the increase of toxicity of EHMC photodegradation products. A similar effect of additional factors was observed by Vione et al. (2015). They have found that in the presence of $\mathrm{TiO}_{2}$ and UV, toxicity of photoproducts increased by $40-50 \%$ with respect to EHMC.

A distinct increase in toxicological response of products, in the case of hydrogen peroxide and sodium hypochlorite, can be explained by formation of cinnamic acid derivatives, among others (esters, aldehydes and alcohols). These

Table 4 Sample toxicity classification system (Ricco et al. 2004; Põllumaa et al. 2014)

\begin{tabular}{ll}
\hline Toxicity $[\%]$ & Classification \\
\hline$<25$ & Not toxic \\
$25-50$ & Low toxicity \\
$50.1-75$ & Toxicity \\
$75.1-100$ & High toxicity
\end{tabular}


Fig. $6 \mathrm{EC}_{50}$ concentration of the systems studied (determined by Microtox ${ }^{\circledR}$ after $180 \mathrm{~min}$ of reaction)

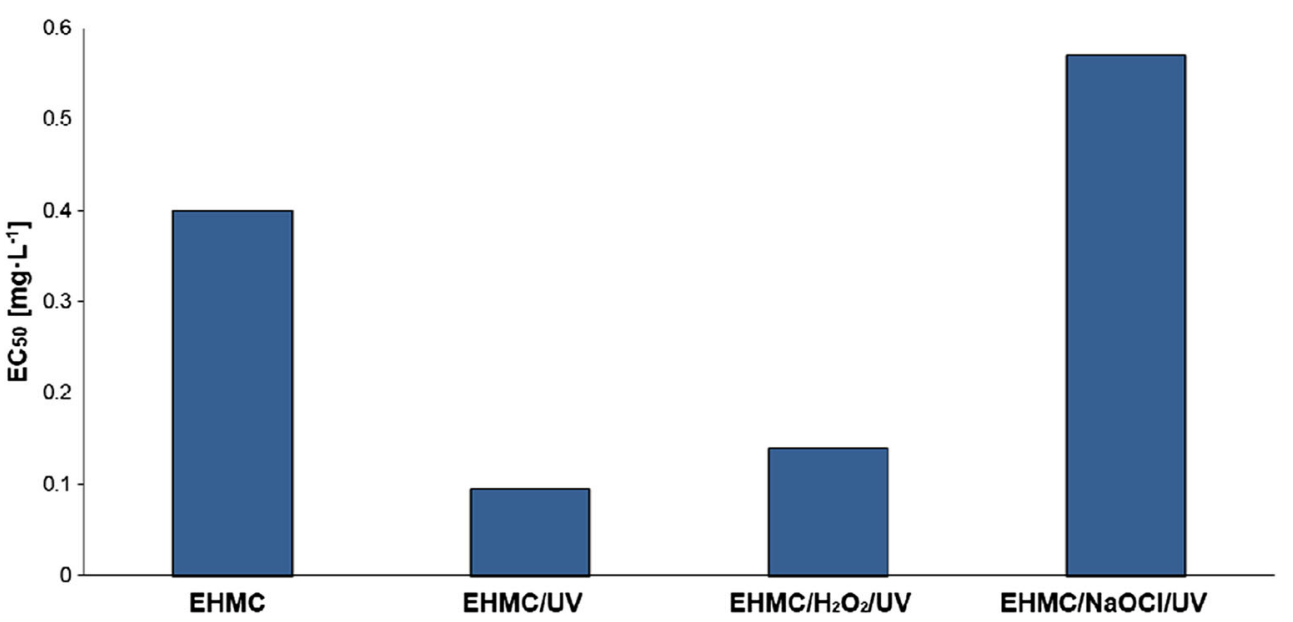

compounds have strong toxic action for some bacterial and fungal species (Narasimhan et al. 2004; Guzman 2014). The highest toxicity in the EHMC/ $\mathrm{NaOCl} / \mathrm{UV}$ system can be attributed to formation of chloroorganic products. On the example of chlorophenols and chlorobenzene, it was found that the toxicity increases with the increase in the number of chlorine atoms in molecule (Pepelko et al. 2005; Zhang et al. 2016). The difference in results between the Microtox ${ }^{\circledR}$ (bacteria) and the other two kits is due to the higher sensitivity of water crustaceans (both Daphnia and Artemia) (S Figs. 13-17).

Moreover, toxicological potential of the tested systems expressed by $\mathrm{EC}_{50}$, calculated in milligrams per liter, was evaluated (Fig. 6). $\mathrm{EC}_{50}$ value was $0.15 \mathrm{mg} \mathrm{L}^{-1}$ for $\mathrm{EHMC} / \mathrm{H}_{2} \mathrm{O}_{2}$ / $\mathrm{UV}$ and $0.094 \mathrm{mg} \mathrm{L}^{-1}$ for $\mathrm{EHMC} / \mathrm{NaOCl} / \mathrm{UV}$, respectively. These values are significantly lower than $\mathrm{EC}_{50}$ obtained for EHMC (0.4 $\left.\mathrm{mg} \mathrm{L}^{-1}\right)$ using bacteria Aliivibrio fisheri.

\section{Conclusions}

As a result of the EHMC transformations, a number of products with different properties other than the substrate are produced. Two main classes of EHMC degradation products have been identified. The first includes oxidation products, which due to their hydrophilic character disperse in water, and some of them can evaporate into the air. Whereas, the second class includes chloroorganic products that probably disperse in air and water and can accumulate in an adipose tissue of living organisms. Both of them can reach anywhere on the planet, so both are a cause of concern. However, it is only their persistence and toxicity that can make them problematic. Oxidation products are characterised by a relatively low durability and small range of dispersal in the environment. Much more harmful to the environment are EHMC chlorination products. Based on the guidelines established in Convention Stockholm (2001), the identified chloroorganic products show the properties of persistent organic pollutants. Degradation half-lives of more than
60 days in water or 180 days in soil, respectively, are used to identify chemicals with high potential to be persistent in the environment, and a half-life of longer than 2 days in air is the screening criterion for atmospheric LRTP (Klasmeier et al. 2006). Products such as chlorobenzene and chlorophenol derivatives have tair $1 / 2$ values longer than 2 days and tsoil1/2 values longer than 6 months. In addition, they are the compounds with proven mutagenic and carcinogenic effect in humans and animals (Igbinosa et al. 2013). Comprehensive risk assessment also included studies on toxicity of the products formed. We observed that oxidation and chlorination products of EHMC show significantly higher toxicity than EHMC alone. It was found that chloroorganic products are a greater environmental hazard. They are characterised by higher toxicity in the environment than oxidation products.

The results obtained can be a valuable information in the context of assessing the quality of water resources, especially in countries where water shortages are replenished by treated sewage. Incomplete removal of EHMC in conventional wastewater treatment plants (Ekpeghere et al. 2016) indicates that this compound is recalcitrant and contaminates the environment. Analysis of the risk of environmental pollution by new pollutants and their transformation products can be useful in assessing water quality in order to ensure maximum safety for water resources.

Open Access This article is distributed under the terms of the Creative Commons Attribution 4.0 International License (http:// creativecommons.org/licenses/by/4.0/), which permits unrestricted use, distribution, and reproduction in any medium, provided you give appropriate credit to the original author(s) and the source, provide a link to the Creative Commons license, and indicate if changes were made.

\section{References}

Armitage JM, Arnot JA, Wania F, Mackay D (2013) Development and evaluation of a mechanistic bioconcentration model for ionogenic organic chemicals in fish. Environ Toxicol Chem 32:115-128. https://doi.org/10.1002/etc.2020 
Axelman J, Broman D, Näf C, Pettersen H (1995) Compound dependence of the relationship $\log \mathrm{K}(\mathrm{ow})$ and $\log \mathrm{BCF} \mathrm{L}$ : a comparison between chlorobenzenes (CBs) for rainbow trout and polycyclic aromatic hydrocarbons (PAHs) for Daphnia. Environ Sci Pollut Res Int 2:33-36. https://doi.org/10.1007/BF02987509

Barón E, Gago-Ferrero P, Gorga M, Rudolph I, Mendoza G, Zapate AM, Díaz-Cruz S, Barra R, Ocampo-Duque W, Páez M, Dabra RM, Eljarrat E, Barceló D (2013) Occurrence of hydrophobic organic pollutants (BFRs and UV-filters) in sediments from South America. Chemosphere 92:309-316. https://doi.org/10.1016/j. chemosphere.2013.03.032

Bohdziewicz J, Dudziak M, Kamińska G, Kudlek E (2016) Chromatographic determination and toxicological potential evaluation of selected micropollutants in aquatic environment - analytical problems. Desalin Water Treat 57:1361-1369. https://doi.org/10. 1080/19443994.2015.1017325

Bonmatin J-M, Giorio C, Girolami V, Goulson D, Kreutzweiser DP, Krupke C, Liess M, Long E, Marzaro M, Mitchell EAD, Noome DA, Simon-Delso N, Tapparo A (2015) Environmental fate and exposure; neonicotinoids and fipronil. Environ Sci Pollut Res 22: 35-67. https://doi.org/10.1007/s11356-014-3332-7

Bradman A, Barr DB, Claus Henn BG, Drumheller T, Curry C, Eskenazi B (2003) Measurement of pesticides and other toxicants in amniotic fluid as a potential biomarker of prenatal exposure: a validation study. Environ Health Perspec 111:1179-1782. https://doi.org/10. 1289/ehp.6259

Christiansson A, Eriksson J, Teclechiel D, Bergman $\AA$ (2009) Identification and quantification of products formed via photolysis of decabromodiphenyl ether. Environ Sci Pollut Re 16:312-321. https://doi.org/10.1007/s11356-009-0150-4

Cuderman P, Heath E (2007) Determination of UV filters and antimicrobial agents in environmental water samples. Anal Bioanal Chem 387:1343-1350. https://doi.org/10.1007/s00216-006-0927-y

Czaplicka M (2004) Sources and transformations of chlorophenols in the natural environment. Sci Total Environ 322:21-39. https://doi.org/ 10.1016/j.scitotenv.2003.09.015

Damiani E, Rosati L, Castagna R, Carloni P, Greci L (2006) Changes in ultraviolet absorbance and hence in protective efficacy against lipid peroxidation of organic sunscreens after UVA irradiation. J Photochem Photobiol B 82:204-213. https://doi.org/10.1016/j. jphotobiol.2005.03.011

De la Cruz N, Giménez J, Esplugas S, Grandjean D, de Alencastro LF (2012) Degradation of 32 emergent contaminants by UV and neutral photo-Fenton in domestic wastewater effluent previously treated by activated sludge. Water Res 46:1947-1957. https://doi.org/10.1016/ j.watres.2012.01.014

Diaz-Cruz MS, Gago-Ferrero P, Liorca M, Barcelo D (2012) Analysis of UV filters in tap water and other clean waters in Spain. Anal Bioanal Chem 402:2325-2333. https://doi.org/10.1007/s00216-011-5560-8

DIRECTIVE 2008/105/EC OF THE EUROPEAN PARLIAMENT AND OF THE COUNCIL of 16 December 2008 on environmental quality standards in the field of water policy, amending and subsequently repealing Council Directives 82/176/EEC, 83/513/EEC, 84/156/ EEC, 84/491/EEC, 86/280/EEC and amending Directive 2000/60/ EC of the European Parliament and of the Council

Ekpeghere KI, Kim U-J, S-H O, Kim H-Y Oh J-E (2016) Distribution and seasonal occurrence of UV filters in rivers and wastewater treatment plants in Korea. Sci Total Environ 542:121-128. https://doi.org/10. 1016/j.scitotenv.2015.10.033

EU 2015/495- COMMISSION IMPLEMENTING DECISION (EU) 2015/495 of 20 March 2015 establishing a watch list of substances for Union-wide monitoring in the field of water policy pursuant to Directive 2008/105/EC of the European Parliament and of the Council

European Commission (EC) Decision 2455/2001/EC of the European Parliament and of the Council of November 20, 2001 establishing the list of priority substances in the field of water policy and amending Directive 2000/60/EC (L 331 of 15-12-2001)

Fent K, Zenker A, Rapp M (2010) Widespread occurrence of estrogenic UV-filters in aquatic ecosystems in Switzerland. Environ Pollut 158: 1817-1824. https://doi.org/10.1016/j.envpol.2009.11.005

Ferrari H, Chen R, Lavezza C, Santinelli I, Longo E, Bramanti (2013) Photodegradation of rhodamine B using the microwave $/ \mathrm{UV} / \mathrm{H}_{2} \mathrm{O}_{2}$ : effect of temperature. Int J Photoenergy 2013:1-12. https://doi.org/ $10.1155 / 2013 / 854857$

Forde MS, Robertson L, Laouan Sidi EA, Côté S, Gaudreau E, Drescher O, Ayotte P (2015) Evaluation of exposure to organophosphate, carbamate, phenoxy acid, and chlorophenol pesticides in pregnant women from 10 Caribbean countries. Environ Sci Process Impacts 17:1661-1671. https://doi.org/10.1039/c5em00247h

Gackowska A, Przybyłek M, Studziński W, Gaca J (2014) Experimental and theoretical studies on the photodegradation of 2-ethylhexyl 4methoxycinnamate in the presence of reactive oxygen and chlorine species. Cent Eur J Chem 12:612-623. https://doi.org/10.2478/ s11532-014-0522-6

Gackowska A, Przybyłek M, Studziński W, Gaca J (2016) Formation of chlorinated breakdown products during degradation of sunscreen agent, 2-ethylhexyl-4 methoxycinnamate in the presence of sodium hypochlorite. Environ Sci Pollut Res 23:1886-1897. https://doi.org/ 10.1007/s11356-015-5444-0

Gao J, Liu L, Liu X, Zhou H, Huang S, Wang Z (2008) Levels and spatial distribution of chlorophenols-2,4-dichlorophenol, 2,4,6trichlorophenol, and pentachlorophenol in surface water of China. Chemosphere 71:1181-1187. https://doi.org/10.1016/j. chemosphere.2007.10.018

Gilbert E, Pirot F, Bertholle V, Falson F, Padois K (2013) Commonly used UV filter toxicity on biological functions: review of last decade studies. Int J Cosmetic Sci 35:208-219. https://doi.org/10.1111/ics. 12030

Guzman JD (2014) Natural cinnamic acids, synthetic derivatives and hybrids with antimicrobial activity. Molecules 19:19292-19349. https://doi.org/10.3390/molecules 191219292

He Y, Wang Y, Lee HK (2000) Trace analysis of ten chlorinated benzenes in water by headspace solid-phase microextraction. J Chromatogr A 874:149-154. https://doi.org/10.1016/S0021-9673(00)00067-4

Hong H, Zhou H, Luan T, Lan C (2005) Residue of pentachlorophenol in freshwater sediments and human breast milk collected from the Pearl River Delta, China. Environ Int 31:643-649. https://doi.org/ 10.1016/j.envint.2004.11.002

Hsieh C-Y, Tsai M-H, Ryan DK, Pancorbo OC (2004) Toxicity of the 13 priority pollutant metals to Vibrio fisheri in the Microtox ${ }^{\circledR}$ chronic toxicity test. Sci Total Environ 320:37-50. https://doi.org/10.1016/ S0048-9697(03)00451-0

Igbinosa EO, Odjadjare EE Chigor VN, Igbinosa IH, Emoghene AO, Ekhaise FO, Igiehon NO, Idemudia OG (2013) Toxicological profile of chlorophenols and their derivatives in the environment: the public health perspective. Sci World J 2013:1-11. https://doi.org/10. $1155 / 2013 / 460215$

Ivanciuc T, Ivanciuc O, Klein DJ (2005) Posetic quantitative superstructure/activity relationships (QSSARs) for chlorobenzenes. J Chem Inf Model 45:870-879. https://doi.org/10.1021/ci0501342

Janjua NR, Kongshoj B, Andersson AM, Wulf HC (2008) Sunscreens in human plasma and urine after repeated whole-body topical application. J Eur Acad Dermatol Venereol 22:456-461. https://doi.org/10. $1111 / j .1468-3083.2007 .02492 . x$

Ji Y, Zhou L, Zhang Y, Ferronato C, Brigante M, Mailhot G, Yang X, Chovelon J-M (2013) Photochemical degradation of sunscreen agent 2- phenylbenzimidazole-5-sulfonic acid in different water matrices. Water Res 47:5865-5875. https://doi.org/10.1016/j.watres. 2013.07.009

Jităreanu A, Tataringa G, Zbancioc AM, Stănescu U (2011) Toxicity of some cinnamic acid derivatives to common bean (Phaseolus 
vulgaris). Not Bot Horti Agrobo 39:130-134 https://doi.org/10. 15835/nbha3927183

Kikuchi A, Saito H, Mori M, Yagi M (2011) Photoexcited triplet states of new UV absorbers, cinnamic acid 2-methylphenyl esters. Photochem Photobiol Sci 10:1902-1909. https://doi.org/10.1039/ C1PP05168G

Kim K, Park H, Lee JH (2014) Urinary concentrations of trichlorophenols in the Korean adult population: results of the national human biomonitoring survey 2009. Environ Sci Pollut Res Int 21:2479-2485. https://doi.org/10.1007/s11356-013-2180-1

Klasmeier J, Matthies M, Macleod M, Scheringer M, Stroebe M, Fenner K, Le Gall AC, Mckone T, Van De Meent D, Wania F (2006) Application of multimedia models for screening assessment of long-range transport potential and overall persistence. Environ Sci Technol 40:53-60. https://doi.org/10.1021/es0512024

Kondo T, Yamamoto H, Tatarazako N, Kawabe K, Koshio M, Hirai N, Morita M (2005) Bioconcentration factor of relatively low concentrations of chlorophenols in Japanese medaka. Chemosphere 61: 1299-1304. https://doi.org/10.1016/j.chemosphere.2005.03.058

Kozani RR, Assadi Y, Shemirani F, Hosseini MRM, Jamali MR (2007) Part-per-trillion determination of chlorobenzenes in water using dispersive liquid-liquid microextraction combined gas chromatography-electron capture detection. Talanta 72:387-393. https://doi.org/10.1016/j.talanta.2006.10.039

Kudlek E, Dudziak M, Bohdziewicz J (2016) Influence of inorganic ions and organic substances on the degradation of pharmaceutical compound in water matrix. Water 8:532-550. https://doi.org/10.3390/ w8110532

Kupper T, Plagellat C, Brändli RC, de Alencastro LF, Grandjean D, Tarradellas J (2006) Fate and removal of polycyclic musks, UV filters and biocides during wastewater treatment. Water Res 40: 2603-2612. https://doi.org/10.1016/j.watres.2006.04.012

Kuramochi H, Takigami H, Scheringer M, Sakai S (2014) Estimation of physicochemical properties of 52 non-PBDE brominated flame retardants and evaluation of their overall persistence and long-range transport potential. Sci Total Environ 491-492:108-117. https://doi. org/10.1016/j.scitotenv.2014.04.004

Lampi P (1992) Cancer incidence following chlorophenol exposure in a community in Southen Finland. Arch Environ Health 47:167-175. https://doi.org/10.1080/00039896.1992.9938346

Langford KH, Reid MJ, Fjeld E, Øxnevad S, Thomas KV (2015) Environmental occurrence and risk of organic UV filters and stabilizers in multiple matrices in Norway. Environ Int 80:1-7. https:// doi.org/10.1016/j.envint.2015.03.012

Legierse KCHM, Sijm DTHM, van Leeuwen CJ, Seinen W, Hermens JLM (1998) Bioconcentration kinetics of chlorobenzenes and the organophosphorus pesticide chlorthion in the pond snail Lymnaea stagnalis - a comparison with the guppy Poecilia reticulate. Aquat Toxicol 41:301-323. https://doi.org/10.1016/S0166-445X(97) 00092-1

León Z, Vlieger J, Chisvert A, Salvador A, Lingeman H, Irth H, Giera M (2010) Identification of the biotransformation products of 2ethylhexyl 4-(N,N-dimethylamino) benzoate. Chromatographia 71: 55-63. https://doi.org/10.1365/s10337-009-1386-3

Li W, Ma Y, Guo C, Hu W, Liu K, Wang Y, Zhu T (2007) Occurrence and behavior of four of the most used sunscreen UV filters in wastewater reclamation plant. Water Res 41:3506-3512. https://doi.org/10. 1016/j.watres.2007.05.039

Liu YS, Ying G-G, Shareef A, Kookana RS (2012) Occurrence and removal of benzotriazoles and ultraviolet filters in a municipal wastewater treatment plant. Environ Pollut 165:225-232. https:// doi.org/10.1016/j.envpol.2011.10.009

Lopez-Antia A, Dauwe T, Meyer J, Maes K, Bervoets L, Eens M (2017) High levels of PFOS in eggs of three bird species in the neighbourhood of a fluoro-chemical plant. Ecotoxicol Environ Saf 139:165-171. https://doi.org/10.1016/j.ecoenv.2017.01.040
Loraine GA, Pettigrove ME (2006) Seasonal variations in concentrations of pharmaceuticals and personal care products in drinking water and reclaimed wastewater in southern. California. Environ Sci Technol 40:687-695-687-695. https://doi.org/10.1021/es051380x

Mackay D, Webster E (2006) Environmental persistence of chemicals. Environ Sci Pollut Res 13:43-49. https://doi.org/10.1065/espr2006. 01.008

MacManus-Spencer LA, Tse ML, Klein JL, Kracunas AE (2011) Aqueous photolysis of the organic ultraviolet filter chemical octyl methoxycinnamate. Environ Sci Technol 45:3931-3937. https://doi. org/10.1021/es103682a

Mostrag A, Puzyn T, Haranczyk M (2010) Modeling the overall persistence and environmental mobility of sulfur-containing polychlorinated organic compounds. Environ Sci Res 17:470-477. https://doi.org/10.1007/s11356-009-0257-7

Nakajima M, Kawakami T, Niino T, Takahashi Y, Onodera S (2009) Aquatic fate of sunscreen agents octyl-4-methoxycinnamate and octyl-4-dimethylaminobenzoate in model swimming pools and the mutagenic assays of their chlorination byproducts. J Health Sci 55: 363-372. https://doi.org/10.1248/jhs.55.363

Narasimhan B, Belsare D, Pharande D, Mourya V, Dhake A (2004) Esters, amides and substituted derivatives of cinnamic acid: synthesis, antimicrobial activity and QSAR investigations. Eur J Med Chem 39:827-834. https://doi.org/10.1016/j.ejmech.2004.06.013

Pepelko WE, Gaylor DW, Mukeriee D (2005) Comparative toxic potency ranking of chlorophenols. Toxicol Ind Health 21:93-111. https://doi. org/10.1191/0748233705th204oa

Philippat C, Wolff MS, Calafat AM, Ye X, Bausell R, Meadows M, Stone J, Slama R, Engel SM (2013) Prenatal exposure to environmental phenols: concentrations in amniotic fluid and variability in urinary concentrations during pregnancy. Environ Health Perspect 121: 1225-1231. https://doi.org/10.1289/ehp.1206335

Poiger T, Buser H-R, Balmer ME, Bergqvist P-A, Müller MD (2004) Occurrence of UV filter compounds from sunscreens in surface waters: regional mass balance in two Swiss lakes. Chemosphere 55:951-963. https://doi.org/10.1016/j.chemosphere.2004.01.012

Põllumaa L, Kahru A, Manusadzianas L (2014) Biotest- and chemistrybased hazard assessment of soils, sediments and solid wastes. J Soil Sci 4:267-275. https://doi.org/10.1007/BF02991123

Ramos S, Homem V, Alves A, Santos L (2015) Advances in analytical methods and occurrence of organic UV-filters in the environmenta review. Sci Total Environ 526:278-311. https://doi.org/10.1016/j. scitotenv.2015.04.055

Ricco G, Tomei MC, Ramadori R, Laera G (2004) Toxicity assessment of common xenobiotic compounds on municipal activated sludge: comparison between respirometry and Microtox $®$. Water Res 38: 2103-2110. https://doi.org/10.1016/j.watres.2004.01.020

Rodil R, Moeder M, Altenburgr R, Schmitt-Jansen M (2009) Photostability and phytotoxicity of sunscreen agents and their degradation mixtures in water. Anal Bioanal Chem 395:1513-1524. https://doi.org/10.1007/s00216-009-3113-1

Rodil R, Quintana JB, Concha-Graña E, López-Mahía P (2012) Emerging pollutants in sewage, surface and drinking water in Galicia (NW Spain). Chemosphere 86:1040-1049. https://doi.org/ 10.1016/j.chemosphere.2011.11.053

Rozas O, Vidal C, Baeza C, Jardim WF, Rossner A, Mansilla HD (2016) Organic micropollutants (OMPs) in natural waters: oxidation by $\mathrm{UV} / \mathrm{H}_{2} \mathrm{O}_{2}$ treatment and toxicity assessment. Water Res 98:109118. https://doi.org/10.1016/j.watres.2016.03.069

Sakkas VA, Giokas DL, Lambropoulou DA, Albanis TA (2003) Aqueous photolysis of the sunscreen agent octyl-dimethyl-p-aminobenzoic acid Formation of disinfection byproducts in chlorinated swimming poolwater. J Chromatogr A 1016:211-222. https://doi.org/10.1016/ S0021-9673(03)01331-1

Sandau CD, Ayotte P, Dewailly E, Duffe J, Norstrom RJ (2002) Pentachlorophenol and hydroxylated polychlorinated biphenyl 
metabolites in umbilical cord plasma of neonates from coastal populations in Quebec. Environ Health Perspect 110:411-417. https:// doi.org/10.1289/ehp.02110411

Santiago-Morales J, Gómez MJ, Herrera-López S, Fernández-Alba AR, García-Calvo E, Rosal R (2013) Energy efficiency for the removal of non-polar pollutants during ultraviolet irradiation, visible light photocatalysis and ozonation of a wastewater effluent. Water Res 47:5546-5556. https://doi.org/10.1016/j.watres.2013.06.030

Santos AJM, Miranda MS, Esteves da Silva JCG (2012) The degradation products of UV filters in aqueous and chlorinated aqueous solutions. Water Res 46:3167-3176. https://doi.org/10.1016/j.watres.2012.03. 057

Schlumpf M, Cotton B, Conscience M, Haller V, Steinmann B, Lichtensteiger W (2001) In vitro and in vivo estrogenicity of UV screens. Environ Health Perspect 109:239-244. https://doi.org/10. 1289/ehp.01109239

Sim W, Lee S, Lee I, Choi S, Oh J (2009) Distribution and formation of chlorophenols and bromophenols in marine and riverine environments. Chemosphere 77:552-558. https://doi.org/10.1016/j. chemosphere.2009.07.006

Straub JO (2002) Concentrations of the UV filter ethylhexyl methoxycinnamate in the aquatic compartment: a comparison of modelled concentrations for Swiss surface waters with empirical monitoring data. Toxicol Lett 131:29-37. https://doi.org/10.1016/ S0378-4274(02)00042-5

Tarazona I, Chisvert A, León Z, Salvador A (2010) Determination of hydroxylated benzophenone UV filters in sea water samples by dispersive liquid-liquid microextraction followed by gas chromatography-mass spectrometry. J Chromatogr A 1217:47714778. https://doi.org/10.1016/j.chroma.2010.05.047

Tor A (2006) Determination of chlorobenzenes in water by drop-based liquid-phase microextraction and gas chromatography-electron capture detection. J Chromatogr A 1125:129-132. https://doi.org/10. 1016/j.chroma.2006.06.081

UNEP. Stockholm Convention on persistent organic pollutants; United Nations Enviroment Programme: Geneva, Switzerland; 2001. http:// www.pops.int

USEPA (United States Environmental Protection Agency), 1991. Water quality criteria summary. Ecological risk assessment branch (WH585) and human risk assessment branch (WH-550D). Health and ecological criteria division, USEPA, Washington, DC, USA

USEPA (United States Environmental Protection Agency), 2014. Update of human health ambient water quality criteria: 2-chlorophenol 9557-8 draft. Available on line at: http://water.epa.gov/scitech/
swguidance/standards/criteria/current/upload/Draft-UpdateofHuman-Health-Ambient-Water-Quality-Criteria-2-Chlorophenol95-57-8.pdf

Vasquez MI, Fatta-Kassinos D (2013) Is the evaluation of "traditional" physicochemical parameters sufficient to explain the potential toxicity of the treated wastewater at sewage treatment plants? Environ Sci Pollut Res 20:3516-3528. https://doi.org/10.1007/s11356-0131637-6

Vione D, Calza P, Galli F, Fabbri D, Medana C (2015) The role of direct photolysis and indirect photochemistry in the environmental fate of ethylhexyl methoxy cinnamate (EHMC) in surface water. Sci Total Environ 15:58-68. https://doi.org/10.1016/j.scitotenv.2015.08.002

Wang Y, Wen Y, Li JJ, He J, Qin WC, Su LM, Zhao YH (2014) Investigation on the relationship between bioconcentration factor and distribution coefficient based on class-based compounds: the factors that affect bioconcentration. Environ Toxicol Pharmacol 38:388-396. https://doi.org/10.1016/j.etap.2014.07.003

Wegmann F, Cavin L, MacLeod M, Scheringer M, Hungerbuhler K (2009) The OECD software tool for screening chemicals for persistence and long-range transport potential. Environ Model Softw 24: 228-237

Werle S, Dudziak M (2013) Evaluation of toxicity of sewage sludge and gasification waste-products. Przem Chem 92:1350-1353 (in Polish)

WHO, 1989. Chlorophenols other than pentachlorophenol, environmental health criteria 93. International Programme on Chemical Safety

WHO, 2003. Chlorophenols in drinking-water. Background document for preparation of WHO guidelines for drinking-water quality. World Health Organization, Geneva (WHO/SDE/WSH/03.04/47)

Xing L, Sun J, Liu H, Yu H (2012) Combined toxicity of three chlorophenols 2,4-dichlorophenol, 2,4,6-trichlorophenol and pentachlorophenol to Daphnia magna. J Environ Monit 14:1677-1683. https://doi.org/10.1039/c2em30185g

Yu-Hong S, Yong-Guan Z (2006) Bioconcentration of atrazine and chlorophenols into roots and shoots of rice seedlings. Environ Pollut 139:32-39. https://doi.org/10.1016/j.envpol.2005.04.035

Zhang S, Lin D, Wu F (2016) The effect of natural organic matter on bioaccumulation and toxicity of chlorobenzenes to green algae. J Hazar Mater 5:186-193. https://doi.org/10.1016/j.jhazmat.2016.03. 017

Zuloaga O, Navarro P, Bizkarguena E, Iparraguirre A, Vallejo A, Olivares M, Prieto A (2012) Overview of extraction, clean-up and detection techniques for the determination of organic pollutants in sewage sludge: a review. Anal Chem Acta 29:7-29. https://doi.org/10. 1016/j.aca.2012.05.016 